\title{
Random regression models for the evaluation of the growth of goats of the Anglonubian breed
}

[Modelos de regressão aleatória para avaliação do crescimento de caprinos da raça Anglonubiana]

G.C. Castro ${ }^{1}$, J.E.G. Campelo², J.L.R. Sarmento ${ }^{2}$, M.D.F. Carvalho. ${ }^{2}$, D.H. Cavalcante ${ }^{3}$, L.A.S. Fiqueiredo Filho ${ }^{4}$

\author{
${ }^{1}$ Aluno de pós-graduação - Universidade Federal do Piauí - Teresina, PI \\ ${ }^{2}$ Centro de Ciências Agrárias - Universidade Federal do Piauí - Teresina, PI \\ ${ }^{3}$ Universidade Federal do Piauí - Bom Jesus, PI \\ ${ }^{4}$ Instituto Federal de Educação, Ciência Tecnologia do Maranhão - Caxias, MA
}

\begin{abstract}
A total of 6593 weight records collected from 796 male and female Anglo-Nubian goats aged up to 130 days, offspring from 29 sires and 225 dams, were used to compare models and estimate genetic parameters throughout the growth curve by applying random regression models. Direct and maternal additive genetic effects and direct and maternal permanent environmental effects were included as random in the models. The contemporary groups were included as fixed effects and goat age at kidding was included as a covariable (linear and quadratic). The choice of the best model was based on the AIC, BIC and AICc criteria. Variance estimates of the four random effects increased as the animals aged. Direct heritability $\left(\mathrm{h}^{2}\right)$ rose from 0.13 to 0.40 with age, whereas maternal heritability showed a low value. Genetic correlations of weight between closer ages were high. The most suitable random regression model to compare the fitting of random effects was that which employed the Legendre polynomials of quadratic order with homogeneous variance (3333-1).
\end{abstract}

Keywords:caprahircus, correlations, heritability, genetic parameters

\section{RESUMO}

Utilizaram-se 6593 pesos de 796 caprinos da raça Anglonubiana, coletados em machos e fêmeas com idade até 130 dias, descendentes de 29 reprodutores e 225 matrizes, com o objetivo de se compararem modelos e de se estimarem parâmetros genéticos ao longo da curva de crescimento com aplicação de modelos de regressão aleatória. Nos modelos, incluíram-se os efeitos genéticos aditivos diretos e maternos e os de ambiente permanente diretos e maternos como aleatórios; os grupos de contemporâneos foram incluídos como efeitos fixos, e a idade da cabra ao parto como covariável (linear e quadrática). A escolha do melhor modelo foi realizada pela avaliação dos critérios AIC, BIC e AICc. As estimativas de variâncias dos quatro efeitos aleatórios cresceram de acordo com o aumento da idade. A herdabilidade direta $\left(h^{2}\right)$ aumentou de 0,13 a 0,40 com a idade, e a materna apresentou baixo valor. As correlações genéticas do peso entre idades mais próximas foram altas. $O$ modelo de regressão aleatório mais adequado ao se comparar o ajuste dos efeitos aleatórios foi o que empregou polinômios de Legendre de ordem quadrática com variância homogênea (3333-1).

Palavras-chave:Capra hircus, correlações, herdabilidade, parâmetros genéticos

\section{INTRODUCTION}

Goats have a high ability to adapt to adverse environmental conditions, which allows their exploitation across the different regions of Brazil.
In the northeastern region of the country, this activity plays an important socioeconomic role, although extensive systems are used with smallsized animals, a growth pattern acquired due to genetic and environmental factors to which

Recebido em 16 de maio de 2019

Aceito em 23 de outubro de 2019

E-mail: geandrocastro1993@gmail.com 
animals are subjected. The Brazilian northeastern region showed a 5.0\% growth between 2008 and 2017 and was responsible for the expansion of the national goat herd in this period (IBGE, 2017). However, this increase was not accompanied by significant improvements in the general management (nutrition, health, breeding) of herds, which usually have unsatisfactory productivity indices due to inadequate management practices coupled with low investment in infrastructure and technology.

Both together and separately, these factors tend to interfere with the productive efficiency of goats and with the identification of genetically superior animals. In this respect, it is important that technologies be developed to improve the general herd management. One of such measures are genetic evaluations, an efficient way to aid the selective process within the herd (Sarmento, 2007).

The adoption of breeding programs and the use of methods to more accurately estimate genetic parameters of local herds can help to increase genetic gains obtained with selection. In this scenario, understanding the animal growth curve pattern, which is frequently evaluated through sequential weight measurements over time, has become the focus of breeding studies so that they can be included in production systems more efficient for the local reality. Within studies developed using this approach in different species of livestock animals, random regression models emerge as another option to be added to the traditional methodology of weight assessment at standard ages (yearling and over-yearling) and non-linear models.

These models are suitable for a genetic analysis of growth, with no dependence upon standardization of weight. Additionally, when all available records are included, genetic parameters can be obtained for all evaluated ages (Passafaro et al., 2016). Therefore, the present study proposes to compare random regression models to determine the best suited to describe changes in genetic parameters throughout the growth curve of Anglo-Nubian goats.

\section{MATERIAL AND METHODS}

This study was approved by the Ethics Committee of the Federal University of Piauí (UFPI) (approval no. 345/17). The research involved weight-age information of Anglo-Nubian goats. The animals belong to the experimental herd of the Federal University of Piauí, located in Teresina, PI, Brazil (5'5' 20" S and 42 $48^{\prime}$ '07' $\mathrm{W})$. Goats were managed for the generation of data to be used for genetic analyses.

The animals were managed in a semi-intensive rearing system where the offspring accompanied their mothers in the pasture from 30 days of age, in an area formed by native vegetation intercropped with cultivated grasses. Andropogon (Andropogongayanus) and Tanzania (Panicum maximum) grasses prevailed for trampling, in addition to elephant grass (Pennisetum purpureum Schum), which was used as roughage, and Tifton (Cynodonspp) as hay.

Dietary supplementation was provided during lactation and in drought periods, using, on average, $300 \mathrm{~g}$ of commercial feed $(16 \%$ crude protein) per animal. Mineral salt and water were provided in the pen where the animals were gathered at the end of the day. Sanitary control consisted of application of an anthelminthic drug when $10 \%$ of the goats showed an egg count per gram of feces (EPG) higher than 1000, as suggested by Costa et al. (2011); and rotation of an active principle at every two years.

During reproductive management, which started in 2001, the goats were allocated to two mating groups. Lactating females composed group 1 and the others group 2. On the resumption of grazing, the animals from the latter group were subjected to a period of controlled service during the rainy period of the year, whereas those in group 1 were subjected to it during the dry period, when they were exposed to two registered sires. By this strategy, the occurrence of mating in one group coincided with the lactation period of the other group in the following years, ensuring contemporary animals in terms of physiological stages within each time of the year (dry and rainy).

A work file was edited from the herd database corresponding to the period of 2001 to 2018 , containing the data structure which included a kinship matrix with 796 animals and 6593 records of weights collected from males and females aged up to 130 days. To better structure the data, weight classes were formed with weight measurements taken at seven-day intervals, totaling 19 weight 
classes. The final file was composed of animals with growth and parental information.

In the analyses, the effects of the contemporary group were considered fixed and goat age at kidding was considered a covariable (linear and quadratic effect), ranging from 10 to 111 months. Sex, birth type, years of birth and weight measurement, birth season and weighing season were grouped, generating 195 contemporary groups (CG). Weight records with values outside the interval of \pm 3 standard deviations relative to the mean of each CG were excluded, and individuals with less than three weight records and/or CG with less than three animals from the data file were also removed.

The data were prepared, formatted and described using SAS® statistical software (Statistical Analyses System 9.0) (Statistical..., 2003). After information consistence was checked and restrictions were set, the final file was summarized in Table 1.

In the initial stage of analysis, the residual was modeled by using a random regression model with Legendre polynomials of cubic order, to adjust the fixed average growth trajectory, maintaining the random part of regression (genetic and environmental effects) with a quadratic order of fit, in order to discover the best model.

Residual variance was divided into classes of 1 (homogeneous) through 5 (heterogeneous), as follows: CL1, for homogeneous; CL2, 1-1 and 2130; CL3, 1-1, 2-43 and 44-130; CL4, 1-1, 2-43, 44-75 and 76-130; and CL5, 1-1, 2-43, 44-75, 76106 and 107-130 days of age (CLn, with " $n$ " representing the number of classes). In the

$$
\begin{gathered}
y_{i j}=F+\sum_{m=1}^{k_{b}-1} b_{m} \varphi_{m}\left(t_{i}\right)+\sum_{m=1}^{k_{A}-1} \alpha_{j m} \varphi_{m}\left(t_{i j}\right)+\sum_{m=1}^{k_{M}-1} \gamma_{j m} \varphi_{m}\left(t_{i j}\right) \\
+\sum_{m=1}^{k_{C}-1} \delta_{j m} \varphi_{m}\left(t_{i j}\right)+\sum_{m=1}^{k_{Q^{-1}}} \rho_{j m} \varphi_{m}\left(t_{i j}\right)+\varepsilon_{i j}
\end{gathered}
$$

where $y_{i j}=$ measurement $\mathrm{i}$ referring to animal $\mathrm{j} ; F=$ set of fixed effects; $b_{m}=$ fixed regression coefficient to model the mean population curve; $\phi_{m}\left(t_{i}\right)=$ regression function that describes the mean population curve according to animal age; $\phi_{m}\left(t_{i j}\right)=$ regression functions that describe the trajectories of each individual $\mathrm{j}$, according to age $\left(\mathrm{t}_{\mathrm{i}}\right)$, for the random direct additive genetic, maternal additive, direct permanent environmental and maternal effects; $\alpha_{j m}, \gamma_{j m}, \delta_{j m}$ and $\rho_{j m}=$ direct additive and maternal genetic, direct permanent environmental and maternal regression coefficients, respectively, for each animal; $k_{b}, k_{a}, k_{m}, k_{c}$ and $k_{q}=$ order of the polynomials to be fitted; and $\varepsilon_{i j=}$ random error associated with age $\mathrm{i}$ of animal $\mathrm{j}$. 
In matrix form, the said model is described as follows:

$\mathrm{Y}=\mathrm{X} \beta+\mathrm{Z}_{1} \alpha+\mathrm{Z}_{2} \gamma+\mathrm{W}_{1} \delta+\mathrm{W}_{2} \lambda+\varepsilon$

$$
\mathrm{V}\left[\begin{array}{c}
\alpha \\
\gamma \\
\delta \\
\lambda \\
\varepsilon
\end{array}\right]=\left[\begin{array}{ccccc}
\mathrm{K}_{A} \otimes A & 0 & 0 & 0 & 0 \\
0 & \mathrm{~K}_{M} \otimes A & 0 & 0 & 0 \\
0 & 0 & \mathrm{~K}_{C} \otimes \mathrm{I}_{N_{a}} & 0 & 0 \\
0 & 0 & 0 & \mathrm{~K}_{Q} \otimes \mathrm{I}_{N_{m}} & 0 \\
0 & 0 & 0 & 0 & R
\end{array}\right] ;
$$

where $\mathrm{Y}=$ vector of observations; $\beta=$ vector of fixed effects; $\alpha=$ random vector of direct additive genetic coefficients; $\gamma=$ random vector of maternal additive genetic coefficients; $\delta=$ vector of direct permanent environmental coefficients; $\lambda=$ vector of maternal permanent environmental coefficient; $\mathrm{X}, \mathrm{Z}_{1}, \mathrm{Z}_{2}, \mathrm{~W}_{1}$ and $\mathrm{W}_{2}=$ corresponding incidence matrices; $\mathrm{K}_{\mathrm{A}}, \mathrm{K}_{\mathrm{M}}, \mathrm{K}_{\mathrm{C}}$ and $\mathrm{K}_{\mathrm{Q}}=$ matrices of variances and covariances between the random regression coefficients for the direct and maternal additive and direct and maternal permanent environmental genetic effects, respectively; $\mathrm{A}=$ kinship coefficient numerator matrix; $\mathrm{I}=$ identity matrix; $\mathrm{N}_{\mathrm{a}}$ and $\mathrm{N}_{\mathrm{m}}=$ number of animals possessing data and number of dams, respectively; $\mathrm{R}=$ residual variance matrix; and $\varepsilon=$ vector of residuals.

The (co)variance components and genetic parameters were estimated by the restricted maximum likelihood method, using the EM algorithm obtained by Wombat software (Meyer, 2018) and adopting $10^{-8}$ as a convergence criterion. The Akaike (AIC), Schwarz' Bayesian (BIC), corrected Akaike (AICc) information criteria were used to compare the models for best fit, as suggested by Bozdogan (1987), as an option given by Wombat software. The said information criteria are represented as follows:

$\mathrm{AIC}=-2 \log \mathrm{L}+2 \mathrm{p}$

$\mathrm{BIC}=-2 \log \mathrm{L}+\mathrm{p} \log (\mathrm{N}-\mathrm{r}(\mathrm{X}))$,

$\mathrm{AICc}=-2 \log l(\theta)+2(p)+2 \frac{p(p+1)}{n-p-1}$

Where

$\mathrm{p}=$ number of model parameters;

$\mathrm{N}=$ total observations;

$r=$ rank of matrix $X$ (incidence matrix for fixed effects).

\section{RESULTS AND DISCUSSION}

The number of observations and weight averages at the different ages are presented in Figure 1, corresponding to the lactating period. Average weight increased from birth to 130 days of age, ranging from 3.01 at birth to $15.92 \mathrm{~kg}$ at 120 days of life.

The highest number of weight measurements occurred from the 1 st to the 42 nd day of life. Organizing the weight into age classes (at sevenday intervals) improved the data structure, providing uniformity to the number of weights per class in this age range, as the animals were weighed weekly, whereas goats of different ages were weighed fortnightly (Figure 1). According to Toral (2008), the pressure level required in estimates influences the number and interval of weight measurements in a study of growth.

By comparing the models with classes of residual variances, we observe that the model considering residual variance $(3,3,3,3-1)$ was the most suitable, based on the employed evaluation criteria (Table 2). It should be stressed that the AIC, BIC and AICc criteria were preferred in this comparison, as they allow the comparison of nonnested models and penalize those with a higher number of parameters (Wonfinger, 1993). 


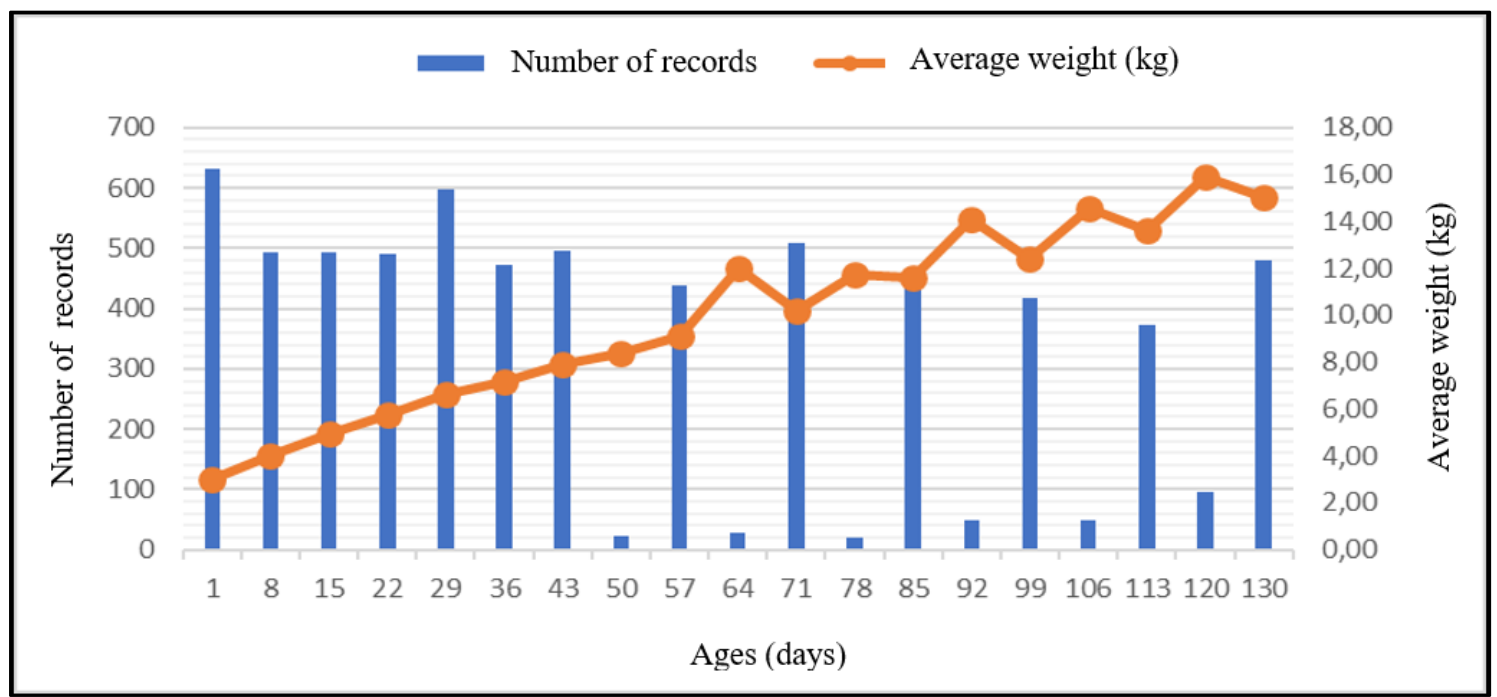

Figure 1. Number of records (bars) and average weight in $\mathrm{kg}$ (row) of Anglonubian animals in the range 1 to 130 days old

Table 2. Random regression models tested for residual variance assessment in age classes

\begin{tabular}{lllll}
\hline Models & \multicolumn{2}{l}{ Statistical Criteria $^{1}$} & & \\
\hline & AIC & BIC & AICc & NP \\
\hline $3333-1$ & -2520.131 & -2604.705 & -2520.230 & 25 \\
$3333-2$ & -2446.728 & -2534.685 & -2446.835 & 26 \\
$3333-3$ & -2.154 .767 & -2246.107 & -2154.882 & 27 \\
$3333-4$ & -2090.437 & -2185.159 & -2090.560 & 28 \\
$3333-5$ & -2087.663 & -2185.769 & -2087.796 & 29 \\
\hline
\end{tabular}

AIC $=$ Akaike information criterion ; BIC $=$ Bayesiano de Schwarz information criterion; AICc $=$ corrected Akaike information criterion; $\mathrm{NP}=$ number of parameters.

The model in which homogeneous residual variances was considered, 3333-1, containing 25 parameters, was also chosen to model the random part of the growth trajectory of the animals in the studied age range and to estimate the (co)variance components and genetic parameters, since it showed the best fit in the evaluated period (Table 3).

Thus, the residual variances tended to be constant throughout the studied period, implying that the environment equally affects the animals at those ages. Because animals are dependent on their mother until weaning, they are subjected to a more homogeneous rearing environment. However, it is important to consider that despite being a relatively short period, it is a life stage during which goats are sensitive to environmental stresses such as decreased milk production by their dams, contact with worm infections on pasture and weaning. Those were the events considered in the division of residual variance classes, but which did not exert sufficient influence to result in heterogeneity of variance in the studied interval.

Similar results were reported by Santoro et al. (2005), who found a better fit for the random regression model considering the homogeneous residual in the description of growth in Nellore animals reared in the state of Pernambuco, Brazil. It is noteworthy that the authors did not take into account the maternal effects as a source of variation in the adopted models, which might have influenced the estimate of genetic parameters. 
Table 3. Random regression models tested for random part evaluation using homogeneous residual variance

\begin{tabular}{lllll}
\hline Models & \multicolumn{2}{l}{ Statistical Criteria $^{1}$} & AICC & NP \\
\hline $3333-1$ & AIC & BIC & -2520.230 & 25 \\
$3334-1$ & -2520.131 & -2604.705 & -2315.639 & 29 \\
$3433-1$ & 2315.506 & -2413.612 & -2119.210 & 29 \\
$3434-1$ & -2119.077 & -2217.183 & -2113.069 & 33 \\
$4333-1$ & -2112.898 & -2224.536 & -2047.952 & 29 \\
$4343-1$ & -2047.819 & -2145.925 & -2050.905 & 33 \\
$4444-1$ & -2050.734 & -2162.371 & -2056.706 & 41 \\
$5333-1$ & -2056.443 & -2195.145 & -1936.733 & 34 \\
$5555-1$ & -1936.551 & -2051.572 & -1944.427 & 61 \\
\hline
\end{tabular}

$\mathrm{AIC}=$ Akaike information criterion; BIC $=$ Bayesiano de Schwarz information criterion $\mathrm{AICc}=$ corrected Akaike information criterion; $\mathrm{NP}=$ number of parameters.

Conversely, the literature presents several studies indicating that considering heterogeneous residual variance structures is more adequate for adjusting goat weight throughout their growth (Sousa et al., 2008; Barazandeh et al., 2012; Kheirabadi and Rashidi, 2016).Increasing the degrees of polynomials (from 3 to 5) to adjust the random regression did not imply improved fitting of the model to the data. Thus, the model that comprised a quadratic fit $(3,3,3,3)$ for all random effects considered was that which provided the best and most parsimonious fit.

The adoption of high-degree polynomials may generate convergence problems, and one quadratic regression for all random effects would be a conservative and prudent choice in studies with cattle, as stated by Meyer (2003). However, there are no precise recommendations about the degree of polynomials to be adopted in random regression models, since the amount of information per weighing date may influence the number of degrees of the polynomial that would best fit the data (Araújo et al., 2016).Estimates of direct and maternal additive genetic, animal and maternal permanent environmental and phenotypic variances showed an upward trend as the animals aged (Figure 2).

The direct additive genetic variances showed very low values at the start of the weighing period for birth weight, mainly $\left(0.088 \mathrm{~kg}^{2}\right)$, but increased until the end of the studied period. According to
Sousa et al. (2010), low magnitude values close to zero at birth may be related to a lack of fit of residual variance when a homogeneous residual variance structure is employed. The variance estimates for direct additive genetic and permanent animal environmental effects were very similar, except that the latter showed slightly higher values.

Animal effects responded similarly to maternal effects, showing a constant upward trend until the end of the studied period, though with low magnitude values. Permanent maternal effect estimates were slightly highebut did not exceed $1.3 \mathrm{~kg}^{2}$. This response pattern is similar to those described by Fischer et al. (2004), who employed random regression models to estimate genetic parameters in lambs in the growing phase; and Araújo et al. (2016), who modeled growth traits of Nellore cattle.

Figure 3 shows direct $\left(\mathrm{h}^{2}\right)$ and maternal $\left(\mathrm{m}^{2}\right)$ heritability estimates and permanent animal $\left(\mathrm{c}^{2}\right)$ and maternal $\left(\mathrm{q}^{2}\right)$ environmental proportions relative to the proportion of phenotypic variance for body weight at ages within the interval of the studied trajectory.

Direct heritability and permanent animal environmental effect behaved similarly throughout the study. The $\mathrm{c}^{2}$ component showed higher values than $h^{2}$, ranging from 0.27 to 0.43 , with Figures increasing since birth. 
Random regression...
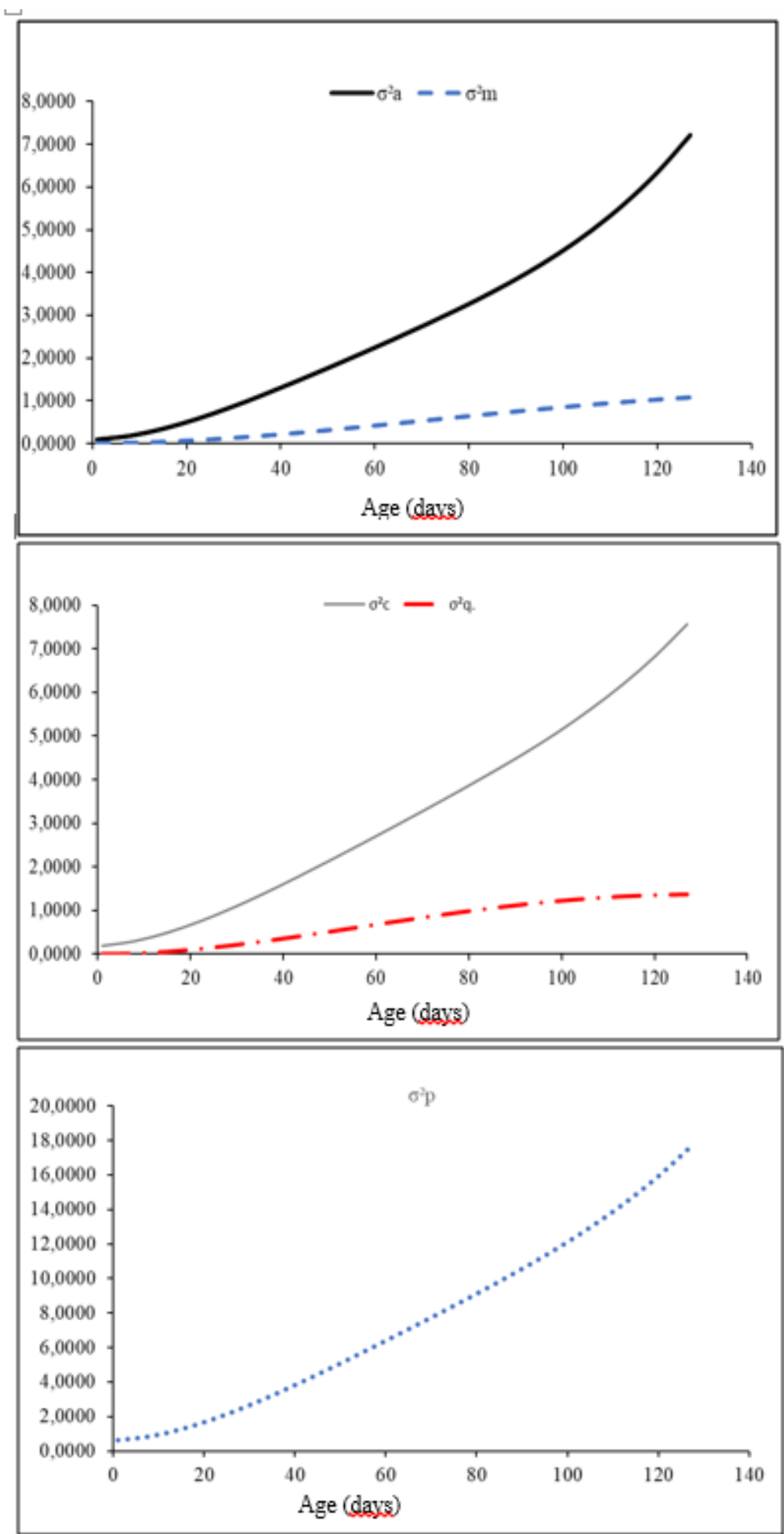

Figure 2. Estimates of components of direct $\left(\sigma^{2} \mathrm{a}\right)$ and maternal $\left(\sigma^{2} \mathrm{~m}\right)$ (above left), permanent direct environment $\left(\sigma^{2} \mathrm{c}\right)$, and maternal $\left(\sigma^{2} \mathrm{q}\right)$ (above right) permanent variances, phenotypic variance (below center) calculated as a function of age in Anglonubian goats with the random regression model 3333 and homogeneous residual variance. 

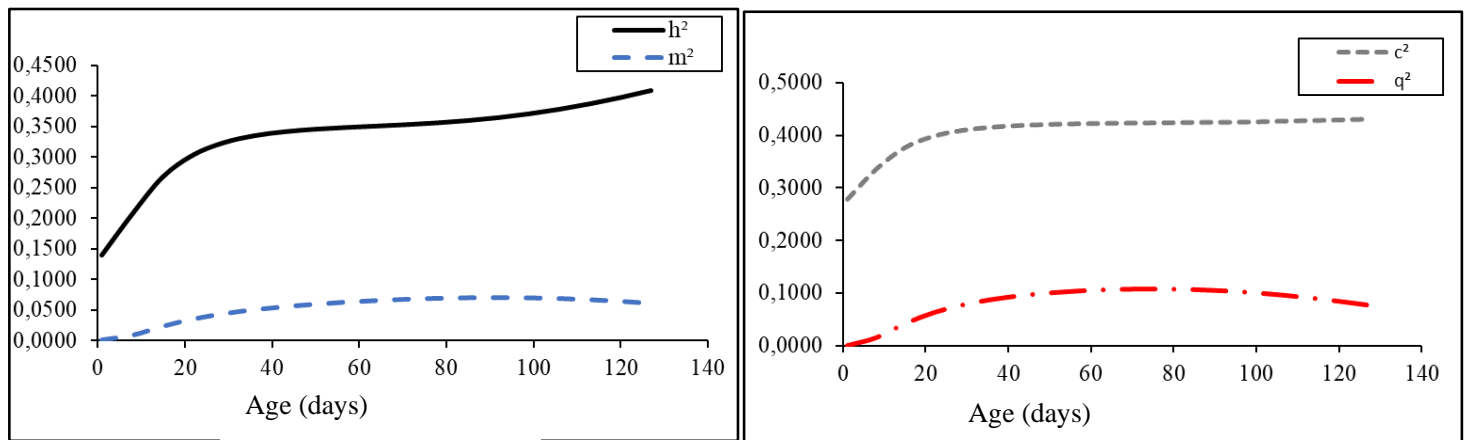

Figure 3. Estimates of direct $\left(\mathrm{h}^{2}\right)$ and maternal $\left(\mathrm{m}^{2}\right)$ variances and heritability, and variance components for animal $\left(\mathrm{c}^{2}\right)$ and maternal $\left(\mathrm{q}^{2}\right)$ permanent environment as a proportion of phenotypic variance in Anglonubian goats with the random regression model 3333 and homogeneous residual variance.

The same estimates for permanent animal environmental effects were found for direct heritability, though with lower magnitude. This finding agrees with the reports of Sarmento et al. (2010), who admitted constant residuals in the genetic evaluation of Santa Inês sheep from birth to 140 days of age, a range similar to that evaluated in the present study. However, there is disagreement regarding the best model fit, considering that the said author obtained better fit to the data when considering heterogeneity of residual variance.

Maternal heritability values $\left(\mathrm{m}^{2}\right)$ were of low magnitude $(<0.06)$. Maternal effects showed less influence than the direct additive effects at all ages, suggesting that the dam had little influence on her offspring. Similar findings have been described in the literature (Fischer et al., 2004). The low maternal heritability values may be reflecting the influence of the low number of dams evaluated, thereby limiting inferences about efficiency in selection for improvement of maternal heritability.

The estimates of direct additive genetic correlation between birth weight and the weights at subsequent ages were positive and moderate, having lower values when compared to the weights measured at the final ages. Overall, weights at closer ages were highly correlated. These values suggest that the common genes interfere with weight at the evaluated ages (Table 4).

Table 4. Estimates of direct additive genetic correlation (above diagonal) and maternal genetics (below diagonal) between the weights at ages PN, P22, P56, P92, P130, obtained by model 3333-1

\begin{tabular}{llllll}
\hline Age (days) & \multicolumn{5}{c}{ Age (days) } \\
\cline { 2 - 6 } & PN & P22 & P56 & P92 & P130 \\
\hline PN & - & 0.670 & 0.562 & 0.544 & 0.488 \\
P22 & -0.691 & - & 0.970 & 0.867 & 0.639 \\
P56 & -0.707 & 1,000 & - & 0.951 & 0.771 \\
P92 & -0.711 & 0.999 & 1.000 & - & 0.929 \\
P130 & -0.712 & 0.997 & 0.998 & 0.999 & - \\
\hline
\end{tabular}

Based on the results, the use of random regression in the study of these animals clearly demonstrates the possibility of interfering with their growth pattern considering the heritability values and genetic correlations between successive weights. Maternal genetic correlation between birth weight and the other ages was negative, which may be a consequence of the number of data analyzed. This explanation also seems to apply to the results presented in this study, given their high magnitude values. Unlike in bovine, the occurrence of twin births may also contribute to this result.

\section{CONCLUSIONS}

Random regression model 3333-1, of quadratic order for random effects and homogeneous residual variance was chosen, based on the 
analyzed criteria, as the most parsimonious.Heritability and correlation values estimated with random regression models considering homogeneous residual variance can be a consistent reference for selection to be performed in the pre-weaning period for replacement in an extensive farming system.

\section{ACKNOWLEDGEMENTS}

The authors thank the Higher Education Personnel Improvement Coordination (CAPES) for the scholarship grant and the Federal University of Piauí.

\section{REFERÊNCES}

ARAÚJO, C.V.; LAUREANO, M.M.M.; NEHLS, W.F. et al. Modelos de regressão aleatória para características de crescimento de bovinos da raça Nelore do estado de Mato Grosso.Arq. Bras. Med. Vet. Zootec., v.68, p.448456, 2016.

BARAZANDEH, A.; MOGHBELI, S.M.; HOSSEIN-ZADEH, N.G.; VATANKHAH, M.Genetic evaluation of growth in Rainy goat usingrandom regression models. Liv. Sci., v.145, p.1-6, 2012.

BOZDOGAN, H. Models election and Akaike's information criterion (AIC): The general theory and its analytical extensions. Psychometrika, v.52, p.345-370, 1987.COSTA, V.M.M.; SIMÕES, S.V.D.; RIET-CORREA, F. Controle das parasitoses gastrintestinais em ovinos e caprinos na região semiárida do Nordeste do Brasil. Pesqui. Vet. Bras., v.31, p.65-71, 2011.

FISCHER, T.M.; VAN DER WERF, J.H.J.; BANKS, R.G.; BOLA, A.J. Description of lamb growth using random regression on field data. Livest. Prod. Sci., v.89, p.175-185, 2004.

KHEIRABADI, K.; RASHIDI, A. Genetic description of growth traits in Markhoz goat using random regression models. Small Ruminant Res., v.144, p.305-312, 2016.

MEYER, K. First estimates of covariance functions for lifetime growth of Angus cattle. Proc. Assoc. Adv. Anim. Breed. Gen., v.15, p.395398, 2003.

MEYER, K. A program for mixed model analyses by restricted maximum likelihooh: user notes. Armidale University of New England, 2018.
PASSAFARO, T.L.; FRAGOMENI, B.O.; GONÇALVES, D.R. et al. Análise genética do peso em um rebanho de bovinos Nelore.Pesqui. Agropecu. Bras., v.51, p.149-158, 2016.

PESQUISA pecuária municipal 2017. Tabela 3939: Efetivo dos rebanhos, por tipo de rebanho, 2008 a 2017. Rio de Janeiro: IBGE, 2017. Disponível em: <https://sidra.ibge.gov.br/tabela/3939>. Acessado em: 1 out. 2018.

SANTORO, K.R.; BARBOSA, S.B.P.; SANTOS, E.S.; BRASIL, L.H.A. Uso de funções de covariância na descrição do crescimento de bovinos Nelore criados no estado de Pernambuco.Rev. Bras. Zootec., v.34, Supl., p.2290-2297, 2005.

SARMENTO, J.L.R. Modelos de regressão aleatória para avaliação genética da curva de crescimento de ovinos da raça Santa Inês. 2007. 101f. Tese (Doutorado em Genética e Melhoramento) - Universidade Federal de Viçosa, Viçosa, MG.

SARMENTO, J.L.R.; TORRES, R.A.; LÔBO, R.N.B. et al. Modelos de regressão aleatória na avaliação genética do crescimento de ovinos da raça Santa Inês.Rev. Bras. Zootec., v.39, p.17231732, 2010.

SOUSA, J.E.R.; SILVA, M.A.; SARMENTO, J.L.R. et al. Avaliação da trajetória média de crescimento de caprinos em modelos de regressão aleatória.Arch. Zootec., v.59, p.267-276, 2010.

SOUSA, J.E.R.; SILVA, M.A.; SARMENTO, J.L.R. et al. Homogeneidade e heterogeneidade de variância residual em modelos de regressão aleatória sobre o crescimento de caprinos AngloNubianos. Pesqui. Agropecu. Bras., v.43, p.17251732, 2008.

STATISTICAL analysis system. User'sguide for Windows environment. Versão 9.0 Cary: SAS Institute, 2003.

TORAL, F.L.B. Número e intervalo de pesagens para estimação de parâmetros de curvas de crescimento em bovinos.Rev. Bras. Zootec., v.37, p. 2120-2128, 2008.

WOLFINGER, R. Covariancestructure selection in general mixed models. Comm. Stat. Simul., v.22, p.1079-1106, 1993. 